\title{
Determination of the selectivity coefficient of a chloride ion selective electrode in alkaline media simulating the cement paste pore solution
}

\author{
G. de Vera ${ }^{a}$, M.A. Climent ${ }^{a}$, C. Antón ${ }^{b}$, A. Hidalgo ${ }^{b}$, C. Andrade ${ }^{\text {b }}$ \\ a Departament d'Enginyeria de la Construcció, Obres Públiques i infrastructura Urbana, Universitat d'Alacant, Ap. 99, 03080 Alacant/Alicante, Spain \\ ${ }^{b}$ instituto de Ciencias de la Construcción Eduardo Torroja. CSIC, C/Serrano Gaivache s/n, 28033 Madrid. Spain
}

Keywords:

Potentiometry

Ionic selective electrode

Sensor

Selectivity coefficient

Chloride

Cement paste pore solution

\begin{abstract}
A B S T R A C T
The measurement of the free chloride concentration in the pore solution of cement paste or concrete is of interest for assessing the probability of corrosion of the steel reinforcements embedded in concrete. This determination is performed through leaching or pore-pressing methods or through embedded potentiometric sensors into the hardened cementitious material. The potentiometric determination of chloride in cement paste pore solutions is limited by hydroxide ion interference, due to the high alkalinity of such media. The potentiometric selectivity coefficients, $\mathrm{k}_{\mathrm{Cl}} \mathrm{OH}^{-}$, are determined for a chloride ionic selective electrode in alkaline solutions simulating the electrolyte present within the pore network of cement paste and concrete. This is done using a fixed interference methodology, with least-squares non-linear curve fitting for obtaining the selectivity coefficients together with other relevant electrode parameters. The limit of detection of the $\mathrm{Cl}$ ISE, due to $\mathrm{OH}$ interference, varies with $\mathrm{pH}$. For the pore solution corresponding to an ordinary Portland cement paste or concrete, this limit can be set between $3 \times 10^{-3} \mathrm{~m}$, and $7 \times 10^{-3} \mathrm{~m}$, i.e., approximately below a chloride concentration value of $1 \times 10^{-2}$ molal. Taking into account these limits of detection the free $\mathrm{Cl}$ concentrations able to depassivate the steel, can be adequately determined by potentiometric measurements with calibrated ISEs in the expressed pore solutions of Portland cement concretes, without significant influence of $\mathrm{OH}$ interference. Nevertheless, this effect can prevent the adequate measurement of low free $\mathrm{Cl}$ concentrations, below the corresponding limit of detection value.
\end{abstract}

\section{Introduction}

Chloride into reinforced concrete is known to be a main responsible of steel corrosion. For this reason the chloride $\left(\mathrm{Cl}^{-}\right)$contents of the concrete raw materials are strictly specified to be under low safe values from the point of view of reinforcement corrosion. Nevertheless, these ions can ingress into concrete when exposed to a marine environment or to interaction with de-icing salts during the service life of structures. This ingress eventually leads to chloride contents high enough to depassivate and corrode the embedded steel. A widely accepted value for the chloride content corrosion threshold is $0.4 \% \mathrm{Cl}^{-}$relative to cement mass in concrete [1], although the actual threshold value may be dependent on several circumstances [2].

Cementitious hydrated phases are able to bind or fix a portion of the $\mathrm{Cl}^{-}$ions present in concrete, but the rest of them remain dissolved in the concrete inner pore solution. This latter portion, sometimes called as the "free chloride", is that considered to be able to corrode the steel. For this reason there have been efforts to develop methods for determining the $\mathrm{Cl}^{-}$concentration of the concrete pore solution. Three types of methodologies have been used for such purpose: leaching methods [3,4], based on the interaction of concrete with water and analysis of the leachates; the pore-pressing technique [5-9], based on the application of high pressures to samples of the cementitious materials allowing to extract small portions of liquid that can be analyzed; and finally the use of embedded sensors in concrete allowing to monitor the "free chloride" content in concrete on-site [10-16].

Direct potentiometry is an appealing non-destructive analytical technique for the determination of the $\mathrm{Cl}^{-}$contents of the solutions obtained by leaching or pore-pressing methods, especially for the latter technique due to the small amount of the obtained liquid samples. Furthermore, the on-site monitoring of $\mathrm{Cl}^{-}$contents in concrete is based on potentiometric sensors [10-16], whose working system is that of a $\mathrm{Cl}^{-}$ionic selective electrode (ISE). It has been also demonstrated that it is possible to determine the activities of chloride ions in synthetic [17,18] or real [19] cement paste pore solutions by potentiometric measurements, but these determinations have a limitation due to the high alkalinity of the pore solution, which shows pH values around 13 , or even higher $[5,19]$. In these conditions the potentiometric response of a $\mathrm{Cl}^{-} \mathrm{ISE}$ can suffer 
interference from hydroxide $\left(\mathrm{OH}^{-}\right)$jons, especially at low $\mathrm{Cl}^{-}$concentrations [20]. This interference has not been quantified before for the case of cement paste pore solution, although abnormally high $\mathrm{Cl}^{-}$activity coefficients were obtained potentiometrically with synthetic and real cement paste pore solutions at $\mathrm{Cl}^{-}$concentrations below approximately $0.01 \mathrm{~m}$, due most probably to $\mathrm{OH}^{-}$ interference [17-19].

Selectivity coefficients $k_{i j}$ are in common use as the quantitative parameter determining the effect of the interfering ions on the potentiometric ISE response [20]. Selectivity coefficients are generally defined with reference to a model electrode response equation, the Nikolskij-Eisenman equation:

$E_{\text {obs }}=E^{-}+\frac{R T}{z_{i} F \log e} \log \left(a_{i}+\sum_{j \neq i} k_{i j} a_{j}^{z_{i} / z_{j}}\right)$

where $E_{\text {obs }}$ is the potential difference measured, $E^{0}$ is a term including all contributions independent of activities $a$, and $z$ is the ion charge. Subscript $i$ stands for the primary ion and subscript $j$ stands for the interfering ions.

It is possible to obtain from literature [20] numerical values for the $\mathrm{k}_{\mathrm{a}^{-}}, \mathrm{OH}^{-}$of ISEs based on solid $\mathrm{AgCl}$ membranes, which are approximately $10^{-2}$. Nevertheless, several authors [20-24] lay stress on the fact that the measured values of the selectivity coefficients of a given ISE, and even its preference for a given species, may be dependent on the procedures and experimental conditions used for their determination. This is especially true in cases where the ISE does not exhibit Nernstian response for both the primary and the interfering ions $[22,25]$. It has been considered also interesting to determine the $k_{i j}$ values under conditions as close as possible to the practical work of the electrode, i.e., using test solutions with compositions and ionic strengths similar to those of real samples [26]. Nevertheless, experimental conditions and protocols have been described recently for obtaining unbiased, thermodynamic selectivity coefficients that are independent of experimental conditions [25,27].

Taking into account the precedent considerations, and the potential interest of the application under study, it is convenient to check if the special conditions imposed by the nature of the concrete inner electrolyte, i.e., high alkalinity and ionic strength [5], may change the selectivity properties of $\mathrm{Cl}^{-}$ISEs. It is also likely that such extreme conditions have not been studied in routine determinations of selectivity coefficients. The objective of this work has been to obtain the values of $k_{\mathrm{Cl}^{-}} \mathrm{OH}^{-}$for a $\mathrm{Cl}^{-}$ISE in alkaline solutions simulating the electrolyte present within the pore network of cement paste and concrete. This determination would allow to quantify in a more reliable way the limitation of the potentiometric determinations of chloride activities due to $\mathrm{OH}^{-}$ interference in such media.

Different experimental methods can be used to determine $k_{i j}$ values $[22,24,25,27]$. The fixed interference (FI) method implies using test solutions with a constant interfering jon concentration while the primary ion concentration is varied. An interesting variation [28] of the FI method uses a single solution of the interfering ion and the primary ion activity is varied by means of small additions, with the electrodes continually in contact, and measuring the cell potential after each addition. This procedure, apart of other advantages [28], reproduces rather closely the working conditions of a $\mathrm{Cl}^{-}$sensor embedded in a cement paste matrix, i.e., permanently exposed to a fixed high $\mathrm{OH}^{-}$activity and progressively exposed to increasing $\mathrm{Cl}^{-}$activities, as these last ions penetrate the concrete cover of the sensor.

Several general recommendations for the determination of selectivity coefficients [24] have been taken into account in this work: the concentrations are defined on a molality $(m)$ base, and the ionic activity coefficients and liquid-junction potentials of the reference electrode have been calculated.

\section{Experimental}

\subsection{Electrochemical cells}

The potential of a $\mathrm{Cl}^{-}$ion selective electrode (lngold type 15213 3000 ) was measured versus a $\mathrm{KCl}$ saturated calomel reference electrode (Russell type CR5). The reference electrode contacted the $\mathrm{Cl}^{-}$ test solution through a Luggin capillary in order to avoid possible test solution contamination. Thus, the electrochemical measuring cell may be expressed as:

\section{SCE $/$ Luggin capillary solution $/ / \mathrm{Cl}^{-}$test solution $/ \mathrm{Cl}^{-}$ISE}

Test solutions were maintained at a temperature of $25.0 \pm 0.1{ }^{\circ} \mathrm{C}$ in a thermostated jacket vessel, stirred and bubbled with $\mathrm{N}_{2}$ to avoid carbonation.

\subsection{Test solutions and measuring procedure}

The expressed pore solutions of cement pastes, mortars and concretes, have been shown to be mainly composed of alkaline hydroxides (especially $\mathrm{KOH}$ and $\mathrm{NaOH}$ in a lesser proportion), with other species $\left(\mathrm{SO}_{4}^{2-}, \mathrm{Ca}^{2+}, \mathrm{AlO}_{2}{ }^{-}, \mathrm{SiO}_{2}\right.$, etc.) being present in muchlower concentrations $[5,6]$. The $\mathrm{OH}^{-}$concentration of the expressed pore solutions of cement mortars and concretes is high (0.04-0.55 M) [29-31], while this concentration may be even higher, up to $0.7 \mathrm{M}$, for pore solutions obtained from pure Portland cement pastes [5]. Given all these facts we have chosen four fixed levels of $\mathrm{OH}^{-}$concentration to measure the $\mathrm{k}_{\mathrm{ar}^{-}, \mathrm{OH}^{-}}$of the $\mathrm{Cl}^{-}$ISE: $0.035 \mathrm{~m}, 0.1 \mathrm{~m}, 0.3 \mathrm{~m}$ and $0.5 \mathrm{~m}$. For the sake of simplicity the alkaline solutions were prepared using only $\mathrm{KOH}$. $\mathrm{Ca}(\mathrm{OH})_{2}$ was not used for these solutions since the $\mathrm{Ca}^{2+}$ concentrations found in cement paste pore solutions are very low [5].

The test solutions series were: $\mathrm{KOH} 0.035 \mathrm{~m}+\mathrm{NaCl}, \mathrm{KOH}$ $0.1 \mathrm{~m}+\mathrm{NaCl}, \mathrm{KOH} 0.3 \mathrm{~m}+\mathrm{NaCl}$, and $\mathrm{KOH} 0.5 \mathrm{~m}+\mathrm{NaCl}$. The approximate $\mathrm{Cl}^{-}$molalities in these series were as follows: $10^{-5} \mathrm{~m}$, $5 \times 10^{-5} \mathrm{~m}, 10^{-4} \mathrm{~m}, 5 \times 10^{-4} \mathrm{~m}, 0.001 \mathrm{~m}, 0.005 \mathrm{~m}, 0.01 \mathrm{~m}, 0.05 \mathrm{~m}$, $0.1 \mathrm{~m}, 0.3 \mathrm{~m}, 0.5 \mathrm{~m}$ and $1 \mathrm{~m}$. Each series was obtained as follows: a volume of $50 \mathrm{ml}$ of $\mathrm{KOH} m_{\mathrm{KOH}}$ ( $m_{\mathrm{KOH}}$ standing for $\mathrm{KOH}$ molality of the corresponding series) were taken. The luggin capillary was also filled with $\mathrm{KOH} m_{\mathrm{KOH}}$ solution. A micropipette was used to do the following sequence of additions to the test solution: $\mathbf{4}$ additions (0.025,0.1, 0.15 and $1 \mathrm{ml}$ ) of $\mathrm{KOH} m_{\mathrm{KOH}}+\mathrm{NaCl} 0.02 \mathrm{~m}, 4$ additions $(0.05,0.45,0.6$ and $5 \mathrm{ml})$ of $\mathrm{KOH} \mathrm{m}_{\mathrm{KOH}}+\mathrm{NaCl} 0.5 \mathrm{~m}$ and 4 additions $(0.9,3.5,4$ and $12 \mathrm{ml})$ of $\mathrm{KOH} \mathrm{m}_{\mathrm{KOH}}+\mathrm{NaCl} 4 \mathrm{~m}$.

After each addition the electrochemical potential of the cell (2) was measured. The test solution $\mathrm{pH}$ was also measured after each addition using a high pH glass electrode (Radiometer pHG211, pH measuring range $0-14$ ). The $\mathrm{pH}$ electrode was calibrated with standard solutions of $\mathrm{pH} 11.0,11.5,12.0,12.5$ and 13.0 [32].

The densities of all solutions used to prepare test solutions were measured weighing thermostatized samples of $5 \mathrm{ml}$ (taken with micropipette). All solutions were prepared using analytical-grade reagents and ultrapure water (Millipore Academic).

\subsection{Theoretical chloride activities}

In real situations, cement matrices are porous media partially saturated with water. The solution filling the pore (i.e., pore water) locally approaches thermodynamic equilibrium with the different constituents of the cement matrix. The resulting pore water solution may be saturated with respect to some matrix constituents, 
resulting in deviations from ideal dilute solution behavior and species activity coefficients significantly different from unity.

Chloride activities in the test solutions were calculated using the Pitzer model. The calculations were carried out with the computer program PHRQPITZ [33], which was developed for the calculation of chemical equilibria in solutions of high jonic strength using the Pitzer model in the temperature range $0-60^{\circ} \mathrm{C}$. A data base of Pitzer interaction parameters is also provided, and the program is accompanied by an interactive input code, PITZINPT.

\section{Results and discussion}

The densities measured on $\mathrm{KOH}+\mathrm{NaCl}$ solutions used to prepare test solutions are shown in Table 1 . These data together with the addition volumes (see Section 2) are needed for the accurate calculation of the $\mathrm{NaCl}\left(\mathrm{Cl}^{-}\right)$molalities of the test solutions.

Fig. 1 shows the electrochemical potentials measured on cell (2) versus $\mathrm{NaCl}$ molality for all test solution serjes. Measured cell potentials range from -5 to $220 \mathrm{mV}$ versus SCE approximately. The interfering effect of $\mathrm{OH}^{-}$on the potential response can be appreciated in Fig. 1. At high chloride concentrations the potential varies approximately in linear form with the logarithm of chloride concentration. At low chloride concentration there is no response of cell potential to chloride concentration, i.e., potential remains constant while chloride molality varies. This curve shape agrees with the Nikolskii-Eisenman model. It is interesting to note in Fig. 1 that the chloride concentration range where chloride is not detected expands to higher values as $\mathrm{KOH}$ molality increases, showing a higher $\mathrm{OH}^{-}$interference.

Table 1

Densities measured on $\mathrm{KOH}+\mathrm{NaCl}$ solutions.

\begin{tabular}{|c|c|c|c|c|}
\hline \multirow[t]{3}{*}{$m_{\mathrm{NaCl}}$} & \multicolumn{4}{|c|}{5 olution density in $\mathrm{kg} / \mathrm{m}^{3}$} \\
\hline & $\mathrm{KOH}$ & $\mathrm{KOH}$ & $\mathrm{KOH}$ & $\mathrm{KOH}$ \\
\hline & $0.035 \mathrm{~m}+\mathrm{NaCl}$ & $0.1 \mathrm{~m}+\mathrm{NaCl}$ & $0.3 \mathrm{~m}+\mathrm{NaCl}$ & $0.5 \mathrm{~m}+\mathrm{NaCl}$ \\
\hline 0 & 1008.7 & 1006.9 & 1018.5 & 1017.6 \\
\hline 0.02 & 1002.1 & 994.2 & 1010.5 & 1015.7 \\
\hline 0.5 & 1023.6 & 1012.0 & 1034.4 & 1040.1 \\
\hline 4 & 1135.5 & 1142.0 & 1151.3 & 1160.7 \\
\hline
\end{tabular}

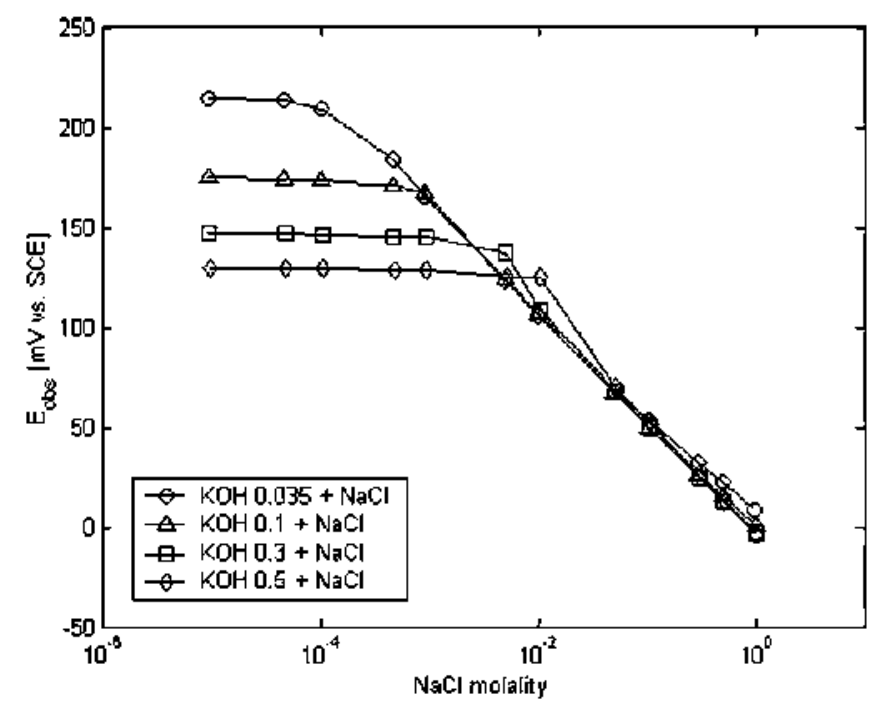

Fig. 1. Measured electrochemical potential. Circle: $\mathrm{KOH} 0.035 \mathrm{~m}+\mathrm{NaCl}$ series. triangle: $\mathrm{KOH} 0.1 \mathrm{~m}+\mathrm{NaCl}$ series, square: $\mathrm{KOH} 0.3 \mathrm{~m}+\mathrm{NaCl}$ series, diamond: $\mathrm{KOH}$ $0.5 \mathrm{~m}+\mathrm{NaCl}$ series.

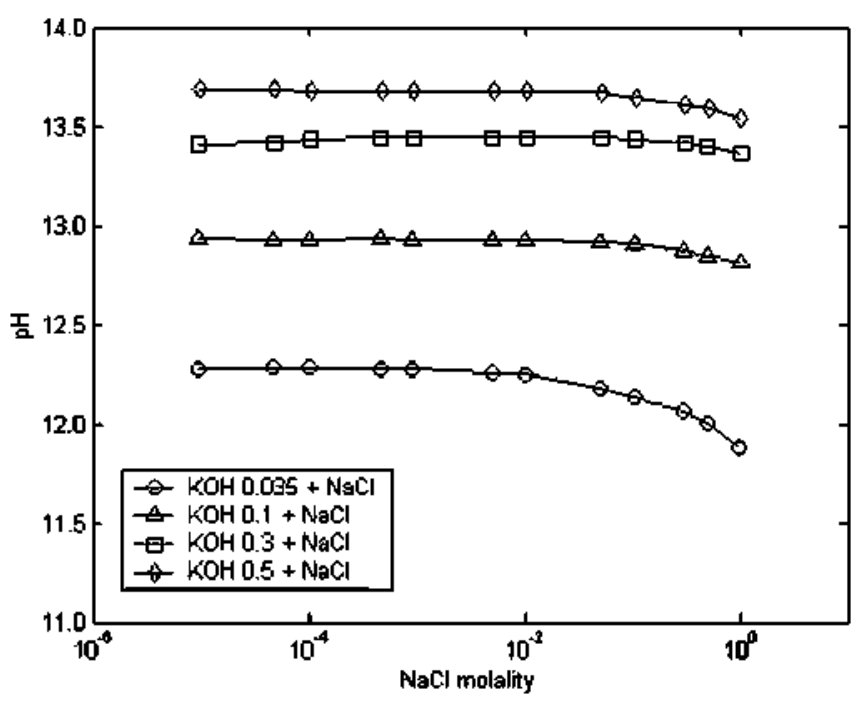

Fig. 2. $\mathrm{pH}$ measured in test solutions versus $\mathrm{NaCl}$ molality. Circle: $\mathrm{KOH}$ $0.035 \mathrm{~m}+\mathrm{NaCl}$ series, triangle: $\mathrm{KOH} 0.1 \mathrm{~m}+\mathrm{NaCl}$ series, square: $\mathrm{KOH} 0.3 \mathrm{~m}+\mathrm{NaCl}$ series, diamond: $\mathrm{KOH} 0.5 \mathrm{~m}+\mathrm{NaCl}$ series.

Measured $\mathrm{pH}$ values are shown in Fig. 2 versus $\mathrm{NaCl}$ molality of test solution for all four series. Values range from 11.9 to 13.7. The pH remains approximately constant within a series. A slight $\mathrm{pH}$ decrease is seen at high chloride concentrations, especially for the lowest $\mathrm{KOH}$ molality series. $\mathrm{pH}$ can be considered constant at chloride concentrations lower than $0.01 \mathrm{~m}$, with the following values measured for each series: $\mathrm{pH} 12.3$ for $\mathrm{KOH} 0.035 \mathrm{~m}+\mathrm{NaCl}$ series, pH 12.9 for $\mathrm{KOH} 0.1 \mathrm{~m}+\mathrm{NaCl}$ series, pH 13.4 for $\mathrm{KOH} 0.3 \mathrm{~m}+\mathrm{NaCl}$ series, and $\mathrm{pH} 13.7$ for $\mathrm{KOH} 0.5 \mathrm{~m}+\mathrm{NaCl}$ series.

Assuming a Nikolskii-Eisenman response (1) for the $\mathrm{Cl}^{-}$ISE, being $\mathrm{Cl}^{-}$the primary jon and $\mathrm{OH}^{-}$the interfering ion, the measured potential difference of cell (2) can be expressed as:

$E_{o b s}=E_{\mathrm{ISE}}^{0}-S \log \left(\mathfrak{a}_{\mathrm{Cl}^{-}}+k a_{\mathrm{OH}^{-}}\right)-E_{j 1}-E_{j 2}-E_{i e f}+N$

where $E_{15 E}^{0}$ is the ISE standard potential, which is taken here as the standard potential of the redox couple AgCl/Ag (i.e., $0.22233 \mathrm{~V}$, versus SHE [34]), Eref is the reference electrode potential (i.e., $0.2412 \mathrm{~V}$, versus SHE [34]), $k$ is the selectivity constant quantifying interference of $\mathrm{OH}^{-}$on $\mathrm{Cl}^{-}$ISE potentiometric response. $E_{j 1}$ is the liquidjunction potential between internal SCE electrolyte (i.e., saturated $\mathrm{KCl}, \beta$-phase) and Luggin capillary solution (i.e., $\mathrm{KOH} m_{\mathrm{KOH}}, \alpha$ phase). $E_{j z}$ is the liquid-junction potential between luggin capillary solution ( $\beta$-phase) and test solution (i.e., $\mathrm{KOH} m_{\mathrm{KOH}}+\mathrm{NaCl} m_{\mathrm{NaCl}}, \alpha-$ phase). Junction potential may be calculated using the Henderson equation [35]:

$E_{j}=\phi^{\beta}-\phi^{\alpha}=\frac{\sum_{i} \frac{z_{j} \mid}{z_{j}} \mathfrak{u}_{i}\left(c_{i}^{\beta}-c_{i}^{\alpha}\right)}{\sum_{i}\left|z_{i}\right| u_{i}\left(c_{i}^{\beta}-c_{i}^{\alpha}\right)}\left(\frac{R T}{F}\right) \ln \frac{\sum_{i}\left|z_{i}\right| \mathbf{u}_{i} c_{i}^{\alpha}}{\sum_{i}\left|z_{i}\right| \mathbf{u}_{i} c_{i}^{\beta}}$

here $z_{i}, u_{i}$, and $c_{i}$ are the respective charge, jonic mobility, and molar concentration of ionic species $i$ in solution. In applying Eq. (4), we have assumed the common practice of substituting ionic mobilities with equivalent ionic conductivities at infinite dilution $\lambda_{i}^{c}[35]$. The sum of the two junction potentials calculated through (4) is plotted in Fig. 3 for all test solution series studied. It ranges from -13 to $1 \mathrm{mV}$. Measured cell potentials range from -5 to $220 \mathrm{mV}$, thus junction potential is not a negligible contribution in Eq. (3). Junction potentials remain approximately constant within a series for chloride concentrations lower than $0.01 \mathrm{~m}$, but their absolute values increase sharply at higher chloride concentrations.

The previous history of the electrode may affect its potentiometric response considerably. For this reason constant $N$ and slope 


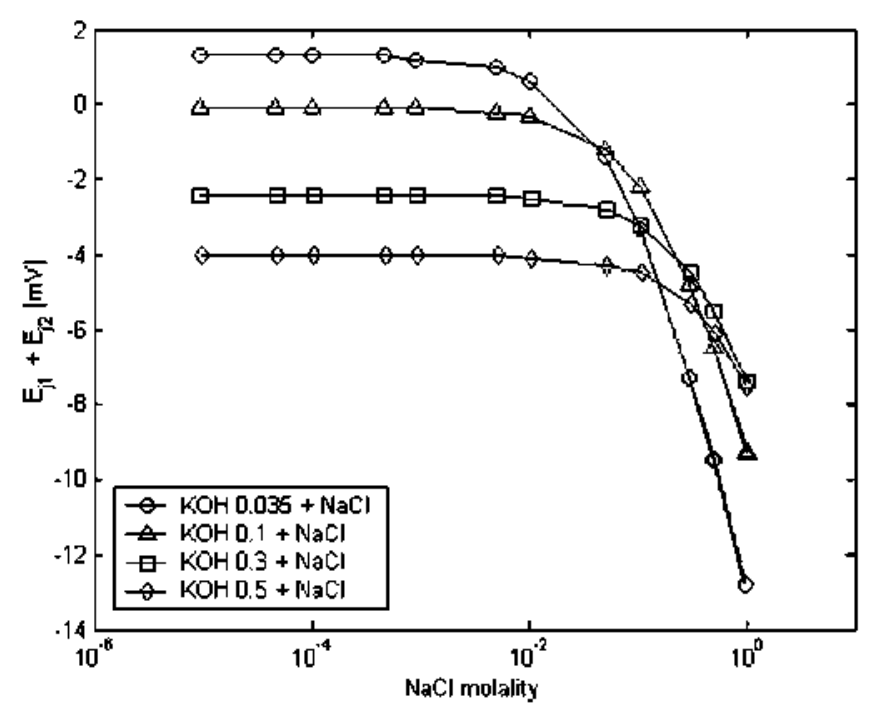

Fig. 3. liquid-junction potential calculated for each series. Circle: $\mathrm{KOH}$ $0.035 \mathrm{~m}+\mathrm{NaCl}$ series, triangle: $\mathrm{KOH} 0.1 \mathrm{~m}+\mathrm{NaCl}$ series, square: $\mathrm{KOH} 0.3 \mathrm{~m}+\mathrm{NaCl}$ series, diamond: $\mathrm{KOH} 0.5 \mathrm{~m}+\mathrm{NaCl}$ series.

$S$ have been introduced in Eq. (3) to account for deviations from ideal ISE behavior. Their theoretical values are, respectively, $0 \mathrm{mV}$ and $59.13 \mathrm{mV}$ (i.e., Nernstian slope).

Chloride activities in the test solutions $\Omega_{\mathrm{C}^{-}}$have been theoretically calculated through Pitzer's model. The corresponding activity coefficients $\gamma_{a^{-}}$(defined in Eq. (5), where $m_{a^{-}}$is the chloride molality of test solution) are shown in Fig. 4.

$\gamma_{\mathrm{q}^{-}}=\frac{a_{\mathrm{Cl}^{-}}}{m_{\mathrm{q}^{-}}}$

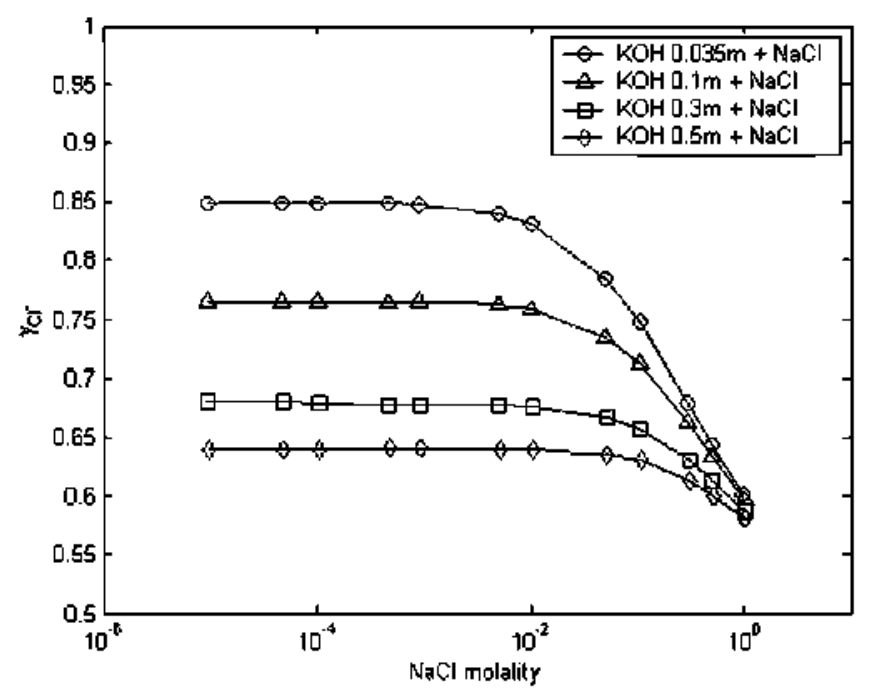

Fig. 4. Theoretical chloride activity coefficients calculated through Pitzer's model.
It can be seen in Fig. 4 that the higher the $\mathrm{KOH}$ molality, the lower the chloride activity coefficient due to higher ionic strength of the medium. Dependence of chloride activity coefficient with chloride concentration is low at low clsloride molalities ( $m_{\mathrm{NaCl}}<0.01$ ), showing the low contribution of chloride to ionic strength under these conditions. Hydroxide activities have been calculated from experimental pH values according to Eq. (6):

$a_{O \mathrm{H}^{-}}=10^{p H-p K_{w}}=10^{p H-14.0}$

The measured cell potential differences have been fitted to Eq. (3) through a least-squares non-linear curve fitting. This is achieved by minimizing the standard deviation, $\sigma$, of the experimental values from best-fit curve.

$\sigma=\sqrt{\frac{\sum_{i=1}^{n}\left(E_{i}^{\text {calc }}-E_{i}^{\text {exp }}\right)^{2}}{n-p}}$

where $E^{e x p}$ are the experimentally measured values of cell potential difference, $E^{\text {calc }}$ are the corresponding values calculated through (3), $n$ are the number of data points fitted and $p$ is the number of fitted parameters (fitted parameters are $N, S$ and $k$, i.e., $p=3$ ). $\sigma$ represents an average separation of the calculated potential values from the experimental ones, and thus it is a measurement of the goodness of the fitting. Parameter values that minimize $\sigma$ have been found applying a simplex method (Nelder-Mead algorithm implemented in MATLAB software). Results are shown in Table 2. Fitting has been done in two ways. Firstly data from each series have been fitted independently, yielding one set of parameters for each $\mathrm{KOH}$ molality. Results are shown in the first four columns of Table 2 . Secondly data from all four series have been fitted together, yielding a set of parameters that represent an average of the parameters sets previously calculated with the other approach, and being a set of parameters applicable to the full range of concentrations of $\mathrm{Cl}^{-}$and $\mathrm{OH}^{-}$. This set of averaged parameters is shown in fifth column of Table 2. Also, regression coefficients $r$, corresponding to the calculated potential versus experimental potential plots, are shown. Table 2 shows high correlation coefficients $(r>0.99)$ and low $\sigma$ values $(\sigma<6 \mathrm{mV})$. It can be stated that the experimental values of the cell potential differences can be adequately fitted to the NikolskijEisenman model (3). Experimental cell potentials and calculated ones using the set of averaged parameters, (fifth column of Table 2), are plotted against chloride activity in Fig. 5.

Theoretical parameter values are also shown for comparison in last column of Table 2. According to the literature $[20,34]$, the theoretical value of $k$ is given by:

$\log k=p K_{S}\left(\mathrm{Ag}_{2} \mathrm{O}\right)-\mathrm{p} K_{S}(\mathrm{AgCl})=-2.032$

where $p K_{5}$ stands for the solubility product. Eq. (8) is applicable to $\mathrm{Cl}^{-}$ISEs consisting on a $\mathrm{AgCl}$ or $\mathrm{Ag}_{2} \mathrm{~S} / \mathrm{AgCl}$ membrane. It is assumed in (8) that, in presence of $\mathrm{OH}^{-}$, silver activity near the surface (and hence electrode potential response) is determined by the exchange equilibrium:

$2 \mathrm{AgCl}(\mathrm{s})+2 \mathrm{OH}^{-}(\mathrm{ac}) \leftrightarrow \mathrm{Ag}_{2} \mathrm{O}(\mathrm{s})+2 \mathrm{Cl}^{-}(\mathrm{ac})+\mathrm{H}_{2} \mathrm{O}(\mathrm{l})$

Table 2

Fitting parameters of the measured cell potentials into Eq. (3)

\begin{tabular}{|c|c|c|c|c|c|c|}
\hline & $\mathrm{KOH} 0.035 \mathrm{~m}+\mathrm{NaCl}$ & $\mathrm{KOH} 0.1 \mathrm{~m}+\mathrm{NaCl}$ & $\mathrm{KOH} 0.3 \mathrm{~m}+\mathrm{NaCl}$ & $\mathrm{KOH} 0.5 \mathrm{~m}+\mathrm{NaCl}$ & Averaged & Theoretical \\
\hline$N(m V)$ & 0.2 & -5.2 & -9.9 & -13.0 & -4.7 & 0.0 \\
\hline$S(\mathrm{mv})$ & 61.44 & 64.32 & 69.07 & 75.12 & 64.39 & 59.13 \\
\hline $\log \mathrm{k}$ & -2.159 & -2.065 & -1.965 & -1.807 & -2.055 & -2.032 \\
\hline$\sigma(m V)$ & 2.5 & 3.4 & 4.7 & 5.8 & 4.5 & - \\
\hline $\mathrm{r}$ & 0.9996 & 0.9991 & 0.9975 & 0.9949 & 0.9979 & - \\
\hline
\end{tabular}




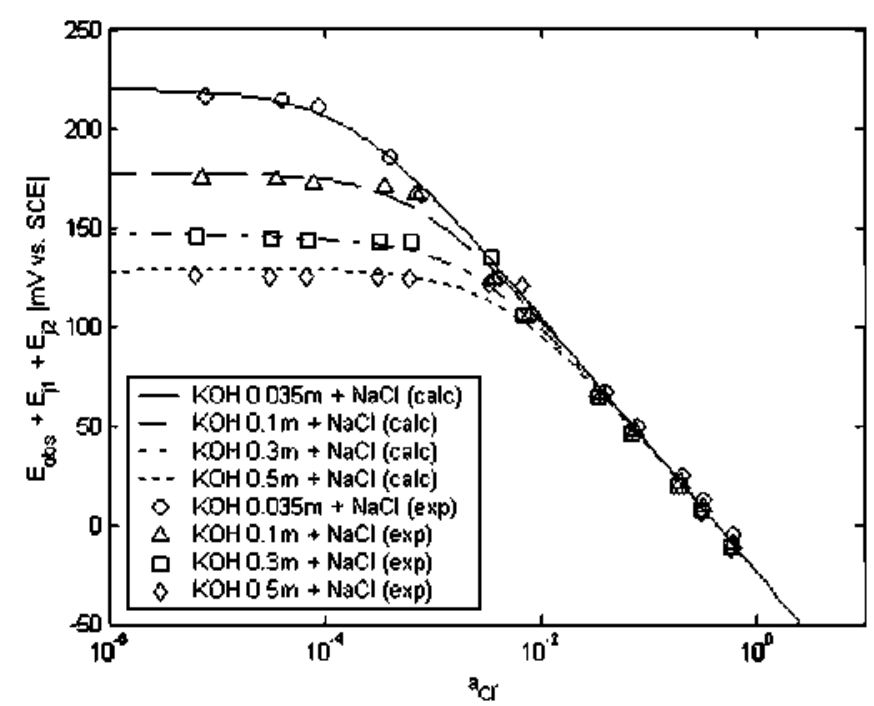

Fig. 5. Comparison of the experimental and calculated cell potentials versus chloride activity in test solutions.

Averaged parameters (fifth column of Table 2 ) are very similar to theoretical ones (sixth column of Table 2). A variation of parameters values with $\mathrm{KOH}$ concentration can be appreciated in Table 2 . $N$ decreases from $0.2 \mathrm{mV}$ to $-13.0 \mathrm{mV}$ when increasing $\mathrm{KOH}$ concentration from $0.035 \mathrm{~m}$ to $0.5 \mathrm{~m}$. $S$ increases from $61.44 \mathrm{mV}$ to $75.12 \mathrm{mV}$, and $k$ increases from $6.9 \times 10^{-3}$ to $15.6 \times 10^{-3}$. The goodness of the fittings and the similarity between calculated and theoretical parameters diminishes slightly when changing $\mathrm{KOH}$ concentration from $0.035 \mathrm{~m}$ to $0.5 \mathrm{~m}$.

The good agreement between the determined average value of the selectivity coefficient $\left(8.8 \times 10^{-3}\right)$ and its theoretical, thermodynamic value $\left(9.3 \times 10^{-3}\right)$, indicates that under these experimental conditions the ISE exhibits Nernstian response slopes for both the primary and the interfering ions [25]. For this reason it may be accepted that the measured values of $k$ are not corrupted due to problems as primary ion contamination or co-extraction processes, and thus these values represent the unbiased selectivity coefficient $k_{\mathrm{Cl}^{-}, \mathrm{OH}^{-}}$[25]. Nevertheless, the slight separations observed for $N, S$ and $k$ from their theoretical values, as the alkalinity of the test solutions is increased (Table 2), indicate that it is not possible to rule out the possibility of modifications of the $\mathrm{AgCl}$ membrane upon prolonged exposure to highly alkaline solutions. This possibility deserves further research, and if confirmed would imply the need to check periodically the behavior of $\mathrm{Cl}^{-}$ISEs when extensively used in contact with such alkaline solutions.

The quantity $E_{o b s}+E_{j 1}+E_{j 2}$ is plotted in Fig. 6 against $a_{\mathrm{Cl}^{-}}+k a_{\mathrm{OH}^{-}}$in a logarithmic scale. The averaged $k$ value is used for calculating the data of Fig. 6. According to Eq. (3) straight lines should be obtained for such a plot. This is the case for the most diluted series $\mathrm{KOH} 0.035 \mathrm{~m}+\mathrm{NaCl}$, but the other series show an anomaly. Divergences from linearity are observed at monotonically increasing $\mathrm{Cl}^{-}$activities, as $\mathrm{KOH}$ molality increases. This fact could also help to explain the divergence of calculated parameters from theoretical ones, for the fittings of experimental cell potentials to Eq. (3), as $\mathrm{KOH}$ concentration increases, see Table 2.

The experimental set-up implies measuring cell potential in a solution of constant $\mathrm{KOH}$ concentration and increasing $\mathrm{NaCl}$ concentration. Initially ISE potential is not able to respond to chloride activity due to the interference of hydroxide. At higher $\mathrm{NaCl}$ concentrations ISE responds to chloride activity and the effect of the interfering ion $\mathrm{OH}^{-}$is negligible, see Fig. 5. It can be seen in Fig. 6 that the potential anomalies occur approximately at the chloride activity values at witch the change of ISE response happen in

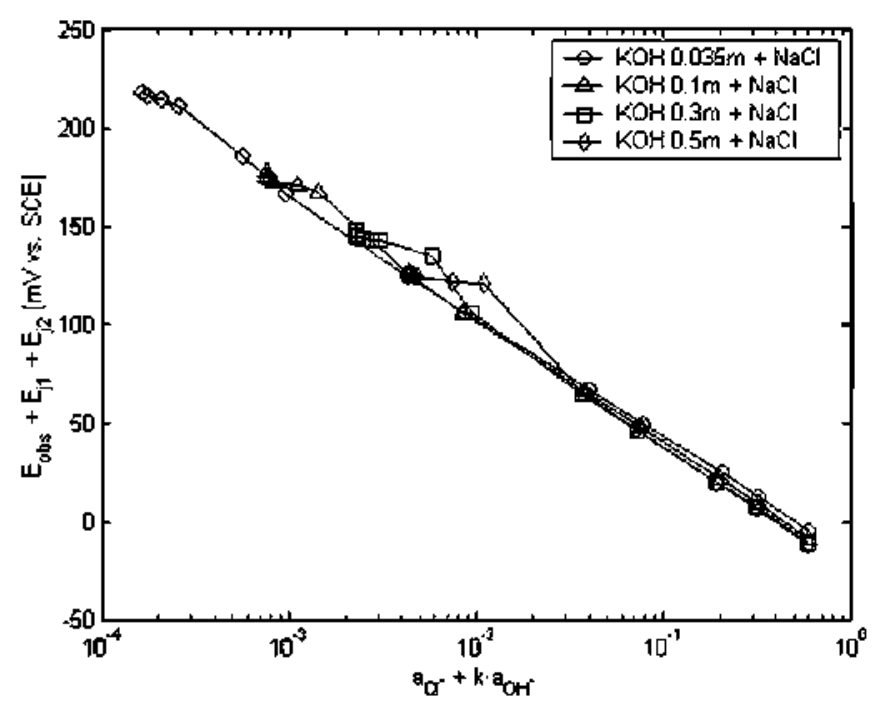

Fig. 6. Plot of $\mathrm{E}_{\mathrm{ubs}}+\mathrm{E}_{j 1}+\mathrm{E}_{i 2}$ versus $\mathbf{a}_{\mathrm{C}^{-}}+k \cdot \mathbf{a}_{\mathrm{OH}^{-}}$, See text for details.

Fig. 5. We can hypothesize that equilibrium (9) and hence potential response to chloride activity cannot be well established until certain chloride concentration is reached.

The limit of detection (LOD) of an ISE can be defined $[21,28]$ as the chloride activity at witch the observed cell potential deviates an amount $S \log 2$ from the Nernstian response. Graphically LOD is given by the intersection of the Nernstian response (linear to $\log a_{\mathrm{a}^{-}}$) with the constant value of the Nikolskii-Eisenman response for low primary ion activity. Thus, the LOD values in this work are given by:

$\mathrm{LOD}=k \cdot \mathfrak{a}_{\mathrm{OH}^{-}}$

Thus, the limit of detection of the clsloride ISE is dependent on the $\mathrm{pH}$. The higher the alkalinity of the medium the higher the limit of detection for chlorides. Taking into account the $\mathrm{pH}$ measured and the averaged $k$ value, the LOD for each series studied are the following activity values: $2 \times 10^{-4}, 7 \times 10^{-4}, 2 \times 10^{-3}$ and $4 \times 10^{-3}$, respectively for the $0.035,0.1,0.3$ and $0.5 \mathrm{~m} \mathrm{KOH}$ series. The corresponding $\mathrm{Cl}^{-}$molal concentrations are: $2 \times 10^{-4}$, $9 \times 10^{-4}, 3 \times 10^{-3}$ and $7 \times 10^{-3}$, respectively. Concentrations lower than these values cannot be accurately determined by potentiometric measurements.

The pore solutions of hardened ordinary Portland cement pastes $[5,8,19]$ and concretes $[29-31]$ have physico-chemical characteristics ( $\mathrm{pH}$ and composition) similar to those of third and fourth solutions series in this work, i.e., $\mathrm{KOH} 0.3 \mathrm{~m}+\mathrm{NaCl}$ and $\mathrm{KOH}$ $0.5 \mathrm{~m}+\mathrm{NaCl}$, respectively. Thus the relevant values of LOD for $\mathrm{Cl}^{-}$ions in these solutions are between $3 \times 10^{-3} \mathrm{~m}$, and $7 \times 10^{-3} \mathrm{~m}$, i.e., approximately below $0.01 \mathrm{~m} \mathrm{Cl}^{-}$. This latter value is in fairly good agreement with the chloride concentrations below which the potentiometric determinations of $\mathrm{Cl}^{-}$activities start to fail, due to $\mathrm{OH}^{-}$interference, in synthetic $[17,18]$ and rea] [19] cement paste pore solutions. Nevertheless, experimental difficulties may rise this LOD to even bigher values [19,21].

It is also interesting to evaluate the impact of the $\mathrm{OH}^{-}$interference upon the potentiometric determinations of free chloride content in cement paste or concrete pore solution, for assessments of the probability of corrosion of steel reinforcements. From practical engineering experience, and for non-carbonated ordinary Portland cement concretes (inner $\mathbf{p H}>13$ ), the steel corrosion risk is considered low for total $\mathrm{Cl}^{-}$contents below $0.4 \%$ relative to cement mass in concrete, while this risk is considered high for $\mathrm{Cl}^{-}$contents higher than $1 \%$ [36]. Table 3 slows the values of free $\mathrm{Cl}^{-}$concentrations 
Table 3

Chloride concentrations of expressed pore solutions obtained from ordinary Portland cement paste (CP) and concrete (C) samples contaminated at mixing with chloride salts at $\left.0.4 \% \mathrm{Cl}^{-}\left(\mid \mathrm{Cl}^{-}\right]_{0.4}\right)$ and $1 \% \mathrm{Cl}^{-}\left(\left[\left.\mathrm{Cl}^{-}\right|_{1}\right)\right.$ levels.

\begin{tabular}{llllll}
\hline Sample & Admixed salt & $\begin{array}{l}{\left[\mathrm{Cl}^{-}\right]_{0.4}} \\
(\mathrm{~mol} / \mathrm{l})\end{array}$ & $\begin{array}{l}\left|\mathrm{Cl}^{-}\right|_{\mathrm{I}} \\
(\mathrm{mol} / \mathrm{fl})\end{array}$ & $\mathrm{pH}$ & Reference \\
\hline $\mathrm{CP}$ & $\mathrm{CaCl}_{2}$ & $0.080^{\mathrm{A}}$ & $0.257^{\mathrm{a}}$ & $13.3^{\mathrm{b}}$ & {$[8]$} \\
$\mathrm{CP}$ & $\mathrm{NaCl}$ & $0.068^{\dagger}$ & - & $13.4^{\mathrm{b}}$ & {$[8]$} \\
$\mathrm{CP}$ & $\mathrm{NaCl}$ & $0.060^{\mathrm{A}}$ & $0.290^{\mathrm{a}}$ & 13.5 & {$[19]$} \\
$\mathrm{C}(50 \mathrm{MPa})$ & $\mathrm{NaCl}$ & 0.021 & 0.140 & 13.7 & {$[29]$} \\
$\mathrm{C}(38 \mathrm{MPa})$ & $\mathrm{NaCl}$ & 0.016 & 0.056 & $13.1^{\mathrm{b}}$ & {$[30]$} \\
$\mathrm{C}(60 \mathrm{MPa})$ & $\mathrm{NaCl}$ & 0.031 & 0.181 & $13.3^{\mathrm{b}}$ & {$[30]$} \\
$\mathrm{C}(73 \mathrm{MPa})$ & $\mathrm{NaCl}$ & 0.053 & $0.258^{\mathrm{a}}$ & $13.3^{\mathrm{b}}$ & {$[30]$} \\
\hline
\end{tabular}

Data in parenthesis are the mean compressive strength values of concretes.

a Interpolated datum.

${ }^{6} \mathrm{pH}$ value calculated from $\mathrm{OH}^{-}$concentration.

of the expressed pore solutions obtained from ordinary Portland cement paste $(\mathrm{CP})$ and concrete $(\mathrm{C})$ samples, which were prepared with different amounts of chloride salts dissolved in the mixing water. The values shown in Table 3 are those corresponding to $0.4 \% \mathrm{Cl}^{-}$relative to cement mass, $\left[\mathrm{Cl}^{-}\right]_{0.4}$ and $1 \% \mathrm{Cl}^{-},\left[\mathrm{Cl}^{-}\right]_{1}$.

It may be appreciated in Table 3 that for total $\mathrm{Cl}^{-}$contents between $0.4 \%$ and $1 \%$, the measured free $\mathrm{Cl}^{-}$concentrations are between $0.016 \mathrm{M}$ and $0.29 \mathrm{M}$. These values are higher than the safe LOD value of $0.01 \mathrm{~m}$, see precedent paragraphs. This means that the free $\mathrm{Cl}^{-}$concentrations able to depassivate the steel, can be adequately determined by potentiometric measurements with calibrated ISEs in the expressed pore solutions of Portland cement concretes, without significant influence of $\mathrm{OH}^{-}$interference. This statement can be extended, in principle, to chloride sensors permanently embedded in Portland cementitious matrices. Nevertheless, in this latter case it must be taken into account that the $\mathrm{OH}^{-}$interference effect can prevent the adequate measurement of low free $\mathrm{Cl}^{-}$concentrations, below the corresponding LOD value, and this fact would count somewhat against the functional requirement of early detection of chloride ingress. The quantification of this latter effect is currently under research.

\section{Conclusions}

The interference of hydroxide ions upon the potentiometric response of a chloride jonic selective electrode has been studied in alkaline solutions simulating cement paste or concrete pore electrolytes. The mixed potentiometric response of the $\mathrm{Cl}^{-}$ISE, to both $\mathrm{Cl}^{-}$and $\mathrm{OH}^{-}$jons, is described through the Nikolskii-Eisenman model. Selectivity coefficients, $\mathrm{kCl}_{\mathrm{Cl}^{-}} \mathrm{OH}^{-}$, together with other electrode parameters, have been determined for the ISE in $\mathrm{KOH}+\mathrm{NaCl}$ solutions representative of the inner cement paste pore solution, using a fixed interference methodology, with least-squares nonlinear fitting of the measured potentials to the model equation. A good agreement between experimental and theoretical values is found for all the electrode parameters, although a slight difference appears at high $\mathrm{KOH}$ concentrations. The limit of detection of the ISE varies with $\mathrm{pH}$. This implies that for the studied media, and in the pH range from 11.9 to 13.7 , chloride concentrations below $2 \times 10^{-4}$ to $7 \times 10^{-3}$ molal cannot be accurately determined by potentiometric measurements, due to the $\mathrm{OH}^{-}$interference. Taking into account these limits of detection, the free $\mathrm{Cl}^{-}$concentrations able to depassivate the steel, can be adequately determined by potentiometric measurements with calibrated ISEs in the expressed pore solutions of Portland cement concretes, without significant influence of $\mathrm{OH}^{-}$interference. Nevertheless, this effect can prevent the adequate measurement of low free $\mathrm{Cl}^{-}$concentrations, below the corresponding limit of detection value.

\section{Acknowledgements}

We thank the funding received for this research from the Ministerio de Educación y Ciencia of Spain and Fondo Europeo de Desarrollo Regional (FEDER) through project B[A2006-05961.

\section{References}

[1] A. Neville, Chloride attack of reinforced concrete: an overview, Mater. 5truct. 28 (1995) 63-70.

[2] C. Alonso, C. Andrade, M. Castellote, P. Castro, Chloride threshold values to depassivate reinforcing bar's embedded in a standardized OPC mortar. Cem. Concr. Res. 30 (2000) 1047-1055.

[3] T. Chaussadent, G. Arliguie, AFREM test procedures concerning chlorides in concrete: extraction and titration methods. Mater. Struct. 32 (217) (1999) $230-234$.

|4| M. Castellote, C. Alonso, C. Andrade, P. Castro, M. Echeverría, Alkaline leaching method for the determination of the chloride content in the aqueous plase of hardened cementitious materials, Cem. Concr. Res. 31 (2001) 233-238.

|5| P. Longuet, L Burglen, A. Zelwer, la phase liquide du ciment hydraté, Rev. Mater. Constr. Trav. Publics 676 (1973) 35-41.

[6] R.S. Barneyback, S. Diamond, Expression and analysis of pore fluids from hardened cement pastes and mortars. Cem. Concr. Res. 11 (1981) 279-285.

[7] C.L. Page, O. Vennesland, Pore solution composition and chloride binding capacity of silica-fume cement pastes, Mater. Construct. (RILEM) 16 (91) (1983) $19-25$

[8] S. Diamond, Chloride concentrations in concrete pore solutions resulting from calcium and sodium chloride admixtures, Cem. Concr. Aggr. (ASTM) 8 (1986) 97-102.

[9] D.J. Anstice, C.L. Page, M.M. Page, The pore solution phase of carbonated cement pastes, Cem. Concr. Res, 35 (2005) 377-383.

[10] B. Elsener, L. Zimmermann, D. Flǘckige, D. Bürchler, H. Böhni, Chloride penetration-non destructive determination of the free chloride content in mortal and concrete, in: Lo. Nilsson. J.P. Ollivier (Eds.). Proceedings of RlLEM International Workshop on Chloride Penetration into Concrete (St. Rémy-lèsChevreuse. France 1995), RlLEM Publications, Bagneux. France, 1997, pp. 1726.

[11] C.P. Atkins, J.D. Scantlebury. P.J. Nedwell, S.P. Blatch, Monitoring chloride concentrations in hardened cement pastes using ion selective electrodes, Cenn. Concr. Res. 26 (1996) 319-324.

[12] M.A. Climent-llorca, E. Viqueira-Pérez, M.M. lópez-Atalaya, Embeddable Ag $\mathrm{AgCl}$ sensors for in-situ monitoring chloride contents in concrete, Cem. Concr. Res. 26 (8) (1996) 1157-1161.

[13] O. Klinghoffer, P, Goltermann, R. Bassler, Smart structures: embeddable sensors for use in the integrated monitoring systems of concrete structures, in: J.R. Casas, D.M. Frangopol, A.5. Nowak (Eds.). Proceedings of First International Conference on Bridge Maintenance. Safety and Management (IABMAS 2002 Barcelona), Intemational Center for Numerical Methods in Engineering (CIMNE), Barcelona, Spain, 2002.

[14] B. Elsener, L. Zimmermann, H. Böhni, Non destructive determination of the free chloride content in cement based materials, Mater. Corros. 54 (2003) 440446.

[15] W.]. McCarter, 0 . Vennesland, Sensor systems for use in reinforced concrete structures, Construct. Build. Mater. 18 (2004) 351-358.

[16] G.5. Duffó, 5.B. Farina, E.A. Arva, C.M. Giordano, C.J. Lafont, Development of al integrated sensor to monitor the corrosion process of reinforced concrete structures, in: R.M. Ferreir'a, J. Gulikers, C. Andrade (Eds.). Proceedings of International RILEM Workshop on Integral Service life Modelling of Concrete Structures (Guimarảes, Portugal 2007), RILEM Publications, Bagneux, France, 2007. pp. 166-173

[17] M.A. Climent, G. de Vera, A. Hidalgo, C. Andrade, C. Alonso, Chloride ion activities in synthetic concrete pore solutions: theoretical models and potentionetric measurements, in: M. Cohen, 5. Mindess, J. Skalny (Eds.) Materials Science of Concrete: The Sidney Diamond Symposium, American Ceramic Society. Westerville, OH, USA, 1998, pp. 285-294.

[18] G. de Vera, A. Hidalgo, M.A. Climent, C. Andrade, C. Alonso, Chloride ion activities in synthetic concrete pore solutions: effect of the accompanying ions. J. Am. Ceram, Soc. $83(2000) 640-644$.

[19] A. Hidalgo, G. de Vera, MA. Climent, C. Andrade, C. Alonso, Measurements of chloride activity coefficients in real portland cement paste pore solutions. J. Am. Ceram. Soc. 84 (2001) 3008-3012.

[20] W.E. Morf, The Principles of Ion-Selective Electrodes and Membrane Transport, Elsevier, 1981.

[21] K. Cammann, Working with lon-Selective Electrodes, Springer Verlag, New York, 1979.

[22] Y. Umezawa, K. Unezawa, H. Sato, Selectivity coefficients for ion-selective electrodes: recommended methods for reporting $K_{A}^{\text {pot }}$ values, technical report of the commission on electroanalytical chemistiy, analytical chemistiy division of the IUPAC, Pure Appl. Chem. 67 (3) (1995) 507-518.

[23] C. Maccà, Determination of potentiometric selectivity. Anal. Clim. Acta 321 (1996) 1-10.

[24] W. Zhang, A. Fakler, C. Demuth, U.E. Spichiger, Comparison of different methods for determining the selectivity coefficient using a magnesiumselective electrode, Anal. Chim. Acta 375 (1998) 211-222. 
[25] E. Lindner, Y. Umezawa, Performance evaluation criteria for preparation and measurement of macro and microfabricated ion-selective electrodes, technical report of the analytical chemistry division of the IUPAC, Pure Appl. Chem. 80 (1) (2008) 85-104.

|26| F. Deyhimi. A method for the determination of potentiometric selectivity coefficients of ion selective electrodes in the presence of several interfering ions. Talanta 50 (1999) 1129-1134.

[27| A. Radu, S. Peper, E. Bakker, D. Diamond, Guidelines for improving the lower detection limit of ion-selective electrodes: a systematic approach, Electroanalysis 19 (2-3) (2007) 144-154.

[28] P. Kane, D. Diamond, Determination of ion-selective electrode characteristics by non-linear curve fitting. Talanta 44 (1997) 1847-1858.

$|29|$ C.L. Page, P. lambert, P.R.W. Vassie, Investigations of reinforcement corrosion. 1. The pore electrolyte phase in chloride contaminated concrete, Mater. Struct. 24 (1991) 243-252.

|30| M.N. Haque, O.A. Kayyali, Free and water soluble clloride in concrete, Cem. Concr. Res. 25 (1995) 531-542.
[31] M. Maslehuddin, C.l. Page, S. Rasheeduzzafar, A.l. Al-Mana, Effect of temperature on pore solution chemistry and reinforcement corrosion in contaminated concrete, in: C.L. Page, P.B. Bamforth, J.W. Figg (Eds.), Corrosion of Reinforcement in Concrete Construction, The Royal Society of Chemistry. Cambridge, UK, 1996, pp. 67-75.

[32] R.G. Bates, V.E. Bower, Alkaline solutions for pH control, Anal. Chem. 28 (1956) 1322-1324.

|33| L.N. Plummer, D.L. Parkhurst, G.W. Fleming. S.A. Dunkle, A computer program incorporating Pitzer's equations for calculation of geochemical reactions in brines, US Geological 5urvey. Water resources investigations report 88-4153. Reston, 1988.

[34] R.C. Weast (Ed.), Handbook of Chemistry and Physics, 66th ed., CRC Press, Boca Raton. Fl, USA, 1985-1986.

[35] A.]. Bard, L.R. Faulkner, Electrochemical Methods, Wiley, New York, 1980.

|36| P. Pedeferri, l. Bertolini, la Durabilità del Calcestruzzo Armato, McGlaw-Hill, Milano, Italy, 2000 (p. 81, only available in Italian). 